\title{
Enzymes as Tools in MIP-Sensors
}

\author{
Aysu Yarman ${ }^{1,2,+}$, Katharina J. Jetzschmann ${ }^{1,+}{ }^{\dagger}$ Bettina Neumann ${ }^{1}$, Xiaorong Zhang ${ }^{1}$, \\ Ulla Wollenberger ${ }^{1}$, Aude Cordin ${ }^{3}$, Karsten Haupt ${ }^{3}$ and Frieder W. Scheller ${ }^{1, *}$ \\ 1 Institute of Biochemistry and Biology, University of Potsdam, Karl-Liebknecht-Str. 24-25, 14476 Potsdam, \\ Germany; aysu.yarman@yahoo.de (A.Y.); jetzschm@uni-potsdam.de (K.J.J.); \\ bettina.neumann@uni-potsdam.de (B.N.); xiaorong.zhang@uni-potsdam.de (X.Z.); \\ uwollen@uni-potsdam.de (U.W.) \\ 2 Faculty of Science, Molecular Biotechnology, Turkish-German University, Sahinkaya Cad. 86, 34820 Beykoz, \\ Istanbul, Turkey \\ 3 Université de Technologie de Compiègne, Sorbonne Universités, CS60319, 60203 Compiègne, France; \\ aude.cordin@utc.fr (A.C.); karsten.haupt@utc.fr (K.H.) \\ * Correspondence: fschell@uni-potsdam.de; Tel.: +49-331-977-6393 \\ + The authors contributed equally to this work.
}

Academic Editor: Peter Lieberzeit

Received: 24 December 2016; Accepted: 20 March 2017; Published: 26 March 2017

\begin{abstract}
Molecularly imprinted polymers (MIPs) have the potential to complement antibodies in bioanalysis, are more stable under harsh conditions, and are potentially cheaper to produce. However, the affinity and especially the selectivity of MIPs are in general lower than those of their biological pendants. Enzymes are useful tools for the preparation of MIPs for both low and high-molecular weight targets: As a green alternative to the well-established methods of chemical polymerization, enzyme-initiated polymerization has been introduced and the removal of protein templates by proteases has been successfully applied. Furthermore, MIPs have been coupled with enzymes in order to enhance the analytical performance of biomimetic sensors: Enzymes have been used in MIP-sensors as "tracers" for the generation and amplification of the measuring signal. In addition, enzymatic pretreatment of an analyte can extend the analyte spectrum and eliminate interferences.
\end{abstract}

Keywords: enzymatic MIP synthesis; template digestion; enzyme tracer; enzymatic analyte conversion; molecularly imprinted polymers

\section{Introduction}

Biological receptors such as antibodies and enzymes are widely used in affinity technology, in applications where specific molecular recognition is required. These include biosensors, assays, bioseparation, but also applications in the biomedical field, such as medical treatment or drug delivery. However, these biomacromolecules have some drawbacks that limit their use in technology, in particular their limited stability and availability.

In order to substitute antibodies and enzymes by fully synthetic materials in the above-mentioned applications, the concept of molecularly imprinted polymers (MIPs) has been created: Monomers are polymerized in the presence of the target analyte or a derivative thereof, resulting in cross-linked polymer networks with cavities that mimic the active sites of biopolymers, e.g., antibodies, enzymes, or hormone receptors [1-4]. Molecularly imprinted polymers are more stable under harsh conditions such as high temperature, extreme $\mathrm{pH}$, and organic solvents, and they are potentially cheaper to produce compared to their biological pendants. However, the affinity and especially the selectivity of MIPs are in general lower than those of their biological counterparts, with some honorable exceptions. This research area is therefore raising increasing interest; at present, more than 1200 papers on 
MIPs are published per year [5-9]. Some ten percent of MIP papers describe artificial receptors for proteins [7,10-13], including enzymes [13-21].

Molecularly imprinted polymers have been mostly developed for binding of targets, thus mimicking the function of antibodies. In addition to these "plastic antibodies", synthetic catalysts have been created which mimic the substrate conversion by enzymes. Stable analogs of the postulated transition state of the catalyzed reaction are used as the template of the MIP to mimic the active center of the enzyme [22-24]. Redox enzymes have been mimicked by integrating metal ions or metal complexes into the polymer matrix of MIPs [25-29]. Moreover, catalytic MIPs have been obtained for reactions for which no natural enzyme catalyst exists [30].

On the other hand, enzymes are useful tools for the preparation of surface-imprinted MIPs and for the optimization of signal transduction in MIP-sensors. Both aspects have not yet been comprehensively discussed in the literature. This article aims to demonstrate the potential of enzymes in the workflow of MIP preparation and for enhancing the analytical performance of MIP-sensors. The following approaches are presented:

- Enzyme-initiated polymerization has been introduced as a green alternative to the well-established chemical polymerization and electrosynthesis.

- Removal of protein templates has been achieved under mild conditions by proteases, especially proteinase $\mathrm{K}$.

Furthermore, MIPs have been coupled with enzymes in order to enhance the analytical performance of biomimetic sensors:

- Enzyme-labeled "tracers" have been used in analogy to competitive immunoassays in MIP sensors.

- The measuring signal of MIP-sensors has been amplified by electro-enzymatic recycling of the redox marker ferricyanide using horseradish peroxidase (HRP).

- The enzymatic pretreatment of the analyte allowed the interference-free electrochemical measurement or the conversion of a non-binding analyte into a target analog of the MIP.

\section{Enzymes in the Workflow of the Preparation of Surface-Imprinted MIPs}

\subsection{Preparation of Surface Imprinted MIPs}

MIPs for low-molecular weight targets are often prepared by classical bulk-imprinting techniques. However, for biomacromolecular targets such as proteins, this still remains challenging due to their large size, high surface complexity, and conformational flexibility. Better accessibility of large target molecules can be achieved by generating the binding sites directly at the surface [31]. Various so-called surface-imprinting techniques were developed in the past few years employing in particular (photo)chemical polymerization, electrochemical synthesis, self-polymerization of dopamine by ambient oxygen, as well as enzyme-initiated polymerization (see Scheme 1).

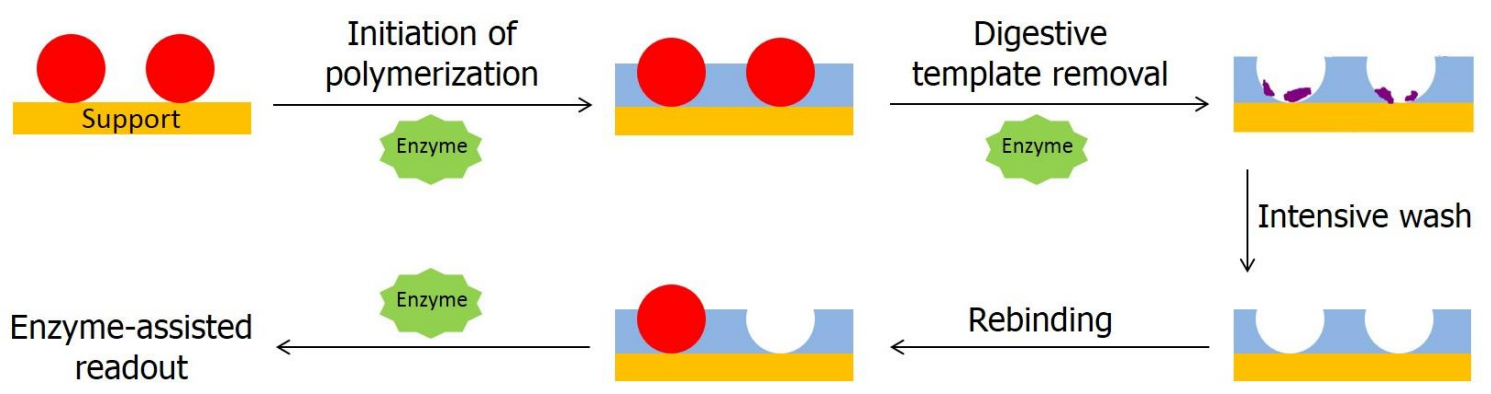

Scheme 1. Enzymes as tools in the workflow of the preparation of molecularly imprinted polymers. 


\subsubsection{Photo- and Chemically Initiated Polymerization}

The initiation of polymerization reactions by the addition of a chemical compound, in combination with UV-irradiation, is a common technique in polymer chemistry and was also applied to the production of MIPs. One approach that combines this technique with the concept of surface-imprinting is the synthesis of MIP nanoparticles (NPs).

In the case of core-shell MIP nanoparticles, the polymer layer is deposited by emulsion or grafting on a preformed support nanosphere. By choosing the appropriate support material, the particle size can be easily varied and specific properties such as fluorescence or magnetism of the core can be beneficial for separation or readout [32]. In this way, MIP nanoparticles for small molecules, e.g., cholesterol [33] but also for proteins, e.g., bovine hemoglobin [34] were prepared.

In 2013, Poma et al. described an approach for the solid-phase synthesis of MIP nanoparticles using a reusable template [35]. Low-molecular weight targets were immobilized on glass beads serving as the solid-phase. Using thermoresponsive polymers, the washing and release of high-affinity MIP nanoparticles from the solid phase could be controlled by temperature changes. In the same year, Ambrosini et al. proposed a comparable approach with elution at lower temperatures compatible with the use of proteinaceous templates [11]. These were immobilized in an oriented way by using affinity ligands in order to improve the binding site homogeneity of the imprinted nanoparticles. Trypsin was chosen as the template, which was later extended to the enzymes kallikrein and ribonuclease A [12]. Metal-chelates served as affinity ligands for surface-bound histidines while the use of the competitive inhibitor $p$-aminobenzamidine as a ligand enabled the polymerization in close proximity of the protein's recognition site. In an earlier work by Cutivet et al., the latter approach was used to prepare the first MIP microgels acting as potent trypsin inhibitors [13].

\subsubsection{Electropolymerization}

Electropolymerization is an elegant way to prepare MIPs directly on the conducting surface of a transducer, e.g., electrodes or quartz crystal micro balance (QCM) and surface plasmon resonance (SPR) chips. Three different methods have been developed with a clear dominance of the last one: Electrochemical generation of the "active" initiator of the radical chain reaction [36], generation of a $\mathrm{pH}$ change by water electrolysis to trigger the deposition of the polymer, e.g., chitosan, at the electrode surface [37], and polymer synthesis by anodic oxidation of functional monomers.

The first successful attempts to electrosynthesize MIPs were performed by Malitesta et al. [38] using o-phenylenediamine (o-PD) for glucose, and in the same year Panasyuk et al. used phenol to synthesize a MIP for phenylalanine [39]. These studies initiated the development of a broad spectrum of electrosynthesized MIPs which are mostly based on pyrrole, derivatives of thiophene, phenylenediamines, and other derivatives of aniline. Most of the electropolymerizable monomers can be deposited from aqueous solutions and buffers can serve as supporting electrolytes. Compared to free radical polymerization initiated generally either thermally or by UV light, electropolymerization most often requires no initiator. Electrically conducting polymers can be grown by the electrochemical oxidation of pyrrole and ethylenedioxythiophene (EDOT) monomers, reaching a thickness appropriate for three-dimensionally structured MIPs [40]. Polypyrrole can be overoxidized by applying high potentials which result in the formation of carboxyl groups and the loss of conductivity. EDOT as a functional monomer offers interactions with the target by hydrogen-bonds, electrostatic, and $\pi-\pi$ interactions, and shows low nonspecific adsorption of proteins [41]. Aniline [42] and related compounds such as o-phenylenediamine [43,44] and o-aminophenol [45] bear functionalities that can participate in hydrogen-bonding, $\pi-\pi-$, and other types of interactions with the template. The most widespread electrochemical polymerization technique for MIPs is cyclic voltammetry (CV). By varying the number of scan cycles and the scan rate, the thickness and the compactness of the deposited polymer film can be controlled, respectively. Potentiostatic deposition lacks control over film compactness, but the film thickness can be precisely adjusted by the charge consumed during electropolymerization $[46,47]$. 


\subsubsection{Self-Polymerization}

Inspired by adhesive amino acids existing in the elastic byssus threads of mussels, Messersmith et al. were the first to present the spontaneous generation of thin polydopamine coatings (2-50 nm) on different organic and inorganic materials (noble metals, metal oxides, semiconductors, ceramics, and synthetic polymers) by self-polymerization of dopamine at alkaline pH (8.5) [48]. Dopamine was selected, since it combines the catechol (3,4-dihydroxy-L-phenylanaline) and amine (lysine) functionalities that were found in high amounts in secreted adhesive mussel proteins [49]. The polymerization reaction is assumed to be initiated by the oxidation of the catechol moiety via ambient oxygen to a quinone, resulting in layers whose thickness is dependent on the immersion time of the material to be coated and could therefore be adjusted to the dimensions of any proteinaceous target.

Zhou et al. introduced the self-polymerization of dopamine as a tool for the imprinting of proteins [50]. In a mixture containing dopamine, $\mathrm{Fe}_{3} \mathrm{O}_{4}$ nanoparticles, and human hemoglobin in slightly alkaline buffer ( $\mathrm{pH} 8.0$ ), the NPs were covered with a ca. $10 \mathrm{~nm}$ thin layer of polydopamine. After removal of the template they were capable of selectively recognizing hemoglobin with good binding capacity. Since then, the technique of self-polymerization has been employed in several studies for the imprinting of proteins on various platforms such as magnetic [51,52], gold [53], or silica nanoparticles [54,55], silicon nanowires [56], 4-vinylphenylboronic acid-based monolithic skeletons [57], gold electrodes [58,59], or multi-walled carbon nanotubes [60]. These studies showed that apart from the advantage of controllable thickness, MIPs comprised of polydopamine exhibit good to excellent binding properties, have high hydrophilicity, biocompatibility, as well as pH (3-11) and longtime stability [61].

\subsubsection{Enzyme-Initiated MIP Synthesis}

Enzymatic polymer synthesis is attractive for green polymer chemistry [62], as enzymes work at mild conditions and have good recyclability as well as biocompatibility. So far, three groups of enzymes have been used to initiate polymerization reactions: oxidoreductases (e.g., HRP, laccase), transferases (e.g., glycosyltransferase, acyltransferase), and hydrolases (cellulase, lipase) [63]. Oxidoreductases catalyze the oxidative polymerization of different organic compounds such as phenols or anilines under the consumption of hydrogen peroxide or other peroxides. In the context of vinyl-based and acrylic polymers, enzyme-initiated polymerization recently also stepped into focus. Thereby, oxidoreductases such as HRP [64] produce the radicals that then initiate radical polymerization.

Very recently, HRP-initiated radical polymerization has been introduced by Haupt's group as a tool for the preparation of MIPs for small molecules such as 2,4-dichlorophenoxyacetic acid (2,4-D) and salicylic acid, but also for the protein trypsin [10]. HRP with $\mathrm{H}_{2} \mathrm{O}_{2}$ as the substrate and a mediator molecule such as acetylacetone generates radicals that can initiate the polymerization of vinyl and acrylate monomers (see Scheme 2).

In order to execute the polymerization in aqueous media, the water-soluble cross-linker 1.4-bis(acryloyl)piperazine was applied. To prevent contamination of the MIP with HRP and to suppress the formation of a polymer shell around the initiator enzyme, a solid-phase synthesis approach was used where the HRP was immobilized on $0.1 \mathrm{~mm}$ glass beads. Using this system, MIP-nanogels with diameters between 50 and $300 \mathrm{~nm}$ were obtained. The possibility of re-using the glass beads with immobilized HRP to initiate more than one batch of polymer particles was demonstrated for 2,4-D imprinted nanoparticles: Four successive batches of MIP and NIP (non-imprinted polymer) were synthesized with the same immobilized HRP. After polymerization, the HRP-charged glass beads can be easily separated from the polymerization mixture and are washed to eliminate any residual unreacted monomers and polymers. The imprinted nanoparticles were characterized by dynamic light scattering and radioligand binding assays. Particle sizes and binding capacity were rather reproducible between different batches. Above six cycles, the nanogel yield started to decrease, indicating partial inactivation of the immobilized enzyme. 
The MIP for 2,4-D showed imprinting factors (IF) of around 5 and good discrimination of structurally related compounds. The MIPs for salicylic acid had a particle size of $150 \mathrm{~nm}$ and a maximum IF of 3. For trypsin, the particles had a size of $25 \mathrm{~nm}$ and an IF of 4 . Regarding their recognition properties, enzyme-initiated MIP nanoparticles were shown to be comparable to or even outperforming their photo-initiated counterparts [10].

A
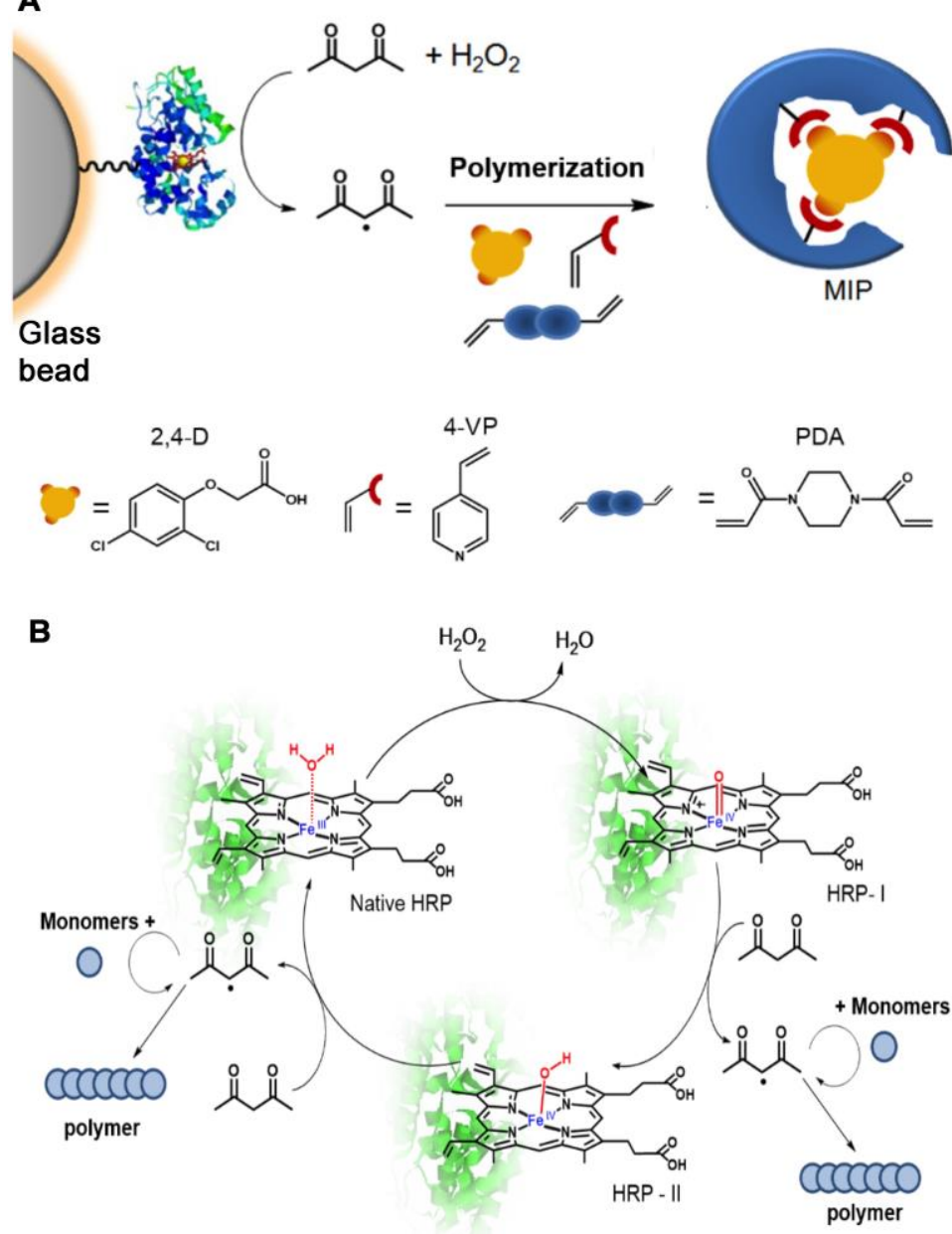

Scheme 2. (A) Schematic representation of the synthesis of molecularly imprinted polymer nanoparticles by immobilized HRP-initiated free-radical polymerization. The monomers used here are 4-vinylpyridine (4-VP) and 1,4-bis(acryloyl)piperazine (PDA). $\mathrm{H}_{2} \mathrm{O}_{2}$ is the substrate of HRP, and acetylacetone is a mediator. The imprinting template is 2,4-D; (B) Simplified catalytic cycle of horseradish peroxidase (HRP) and the commonly accepted formation of radicals. Reproduced from Ref. [10], with permission. Copyright from John Wiley and Sons (2017).

\subsection{Template Removal by Enzymes}

The essential prerequisite for template removal is not to alter the binding sites and integrity of the polymer structure. In fact, the choice of regeneration conditions is a trade-off between complete removal of the target and preservation of the integrity of the binding sites. Methods applied include the application of chaotropic agents, extraction by organic solvents, the use of highly acidic or basic solutions and/or surfactants such as sodium dodecylsulfate (SDS) or Tween 20, sometimes at elevated temperatures [7], and electroelution [10,13,31].

For protein targets, an alternative to harsh solvent extraction is proteolytic digestion, e.g., by proteinase $\mathrm{K}$ or trypsin (see Scheme 1). Proteinase $\mathrm{K}$ is a serine protease with broad cleaving specificity. The predominant site of cleavage is the peptide bond adjacent to the carboxyl group 
of aliphatic and aromatic amino acids with blocked alpha amino groups [52]. It is still active even in the presence of some common chemicals which denature proteins, such as SDS, urea, and ethylenediaminetetraacetic acid (EDTA) [65,66]. Therefore, proteinase $\mathrm{K}$ is commonly used for nucleic acid isolation and for general protein degradation in cell lysates [65].

Proteinase K and trypsin have been used for template removal in protein imprinting. The process can be performed under mild conditions, which is favorable for retaining the polymer structure. Since after digestion protein fragments still remain in the binding sites of the MIP, intensive washing is required. Hawkins et al. achieved efficient removal of hemoglobin from a polyacrylamide-based MIP [67]. Proteinase $\mathrm{K}$ has been successfully used to remove myoglobin (16.7 kDa) from a polyaminophenol-layer [45], canceroembryonal antigen (CEA) from a polypyrrole based MIP [68], trypsin from methacryloylaminobenzamidine based microgels [13], as well as concanavalin A (ConA) $(102 \mathrm{kDa})$ from a polyscopoletin-matrix [69]. In the latter case, proteinase $\mathrm{K}$ was used in combination with Tween 20.

\section{Enzymes for the Enhancement of the Analytical Performance of MIP Sensors}

\subsection{Signal Amplification in Electrochemical MIP Sensors}

In addition to the utilization in the synthesis of MIPs, electrochemical methods are also used for measuring the binding of both low and high molecular weight targets. Amperometry, differential pulse voltammetry (DPV), and impedance spectroscopy are more sensitive and simple compared to quartz crystal microbalance (QCM) or surface plasmon resonance (SPR). Electrochemical pulse methods offer the possibility to eliminate signals of easily oxidizable substances such as ascorbic acid and catecholamines by selecting the potential window, however at the expense of increased measuring times. Two major principles have been applied:

(i) Electroactive targets, such as morphine, paracetamol, tamoxifen, and diclofenac can permeate through the cavities of the MIP to the electrode and an electrochemical signal can be generated by the conversion of the target using different electrochemical methods. This principle has been frequently used for drugs which contain phenolic structures but also for a few proteins which show direct electron transfer, e.g., cytochrome $c$, hemoglobin, and hexameric tyrosine-coordinated heme protein (HTHP) [21,70,71].

(ii) Binding of the target modulates the diffusive permeation of redox markers in a concentration-dependent manner. This effect has been frequently applied to characterize each step of MIP preparation for electro-inactive targets, such as melamine, methyl parathion, phenobarbital, caffeine, 17ß-estradiol, acetylsalicylic acid, and warfarin [72-76]. In addition, this method is frequently applied to quantify the binding of the target analyte. However, it supplies an indirect signal which integrates all changes of the MIP-layer. Using this approach, several papers claim measuring ranges over more than four decades of target concentration and lower limits of detection (LOD) in the sub-nanomolar range for both low- $[77,78]$ and high-molecular weight targets [79-81]. Rebinding of the target in the pores of the MIP could be strong for small molecules. On the other hand, the film thickness for surface imprinted layers is lower than the dimension of macromolecular targets. Thus, affinity constants for non-covalent MIPs could hardly reach the sub-nanomolar region. From the practical point of view, it seems questionable to evaluate the tiny current decreases per concentration decade of the cyclic and differential pulse voltammograms. 


\section{Signal amplification}
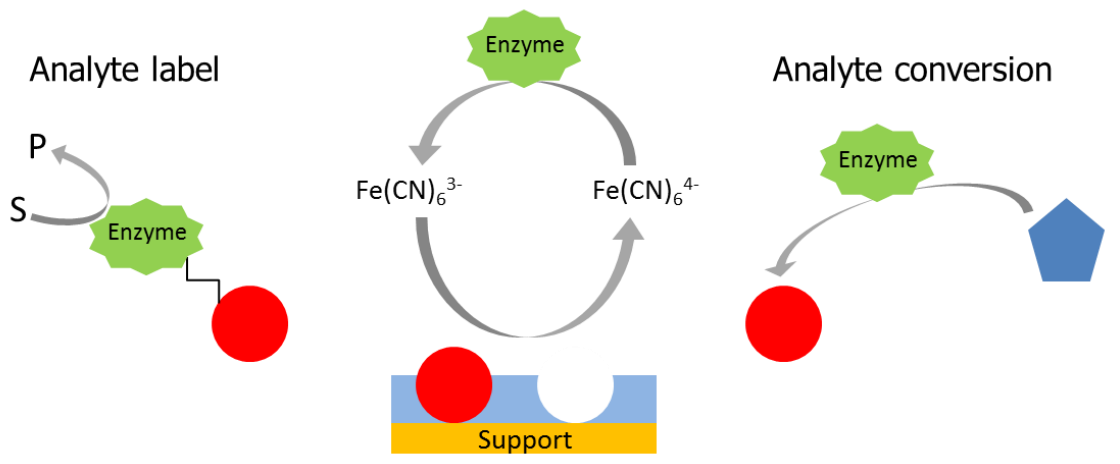

Scheme 3. Enzymes as tools in the readout of MIP sensors.

Enzymes offer further possibilities to enhance the analytical performance and sensitivity of electrochemical MIP sensors as they can be used for signal amplification (see Scheme 3). Electro-enzymatic recycling of the redox marker was successfully applied by Lian et al. for signal amplification in the readout of the target binding of MIPs for the antibiotic kanamycin [82]. In the first system, the ferrocyanide which is formed at the MIP-covered electrode is enzymatically reoxidized by peroxide in the presence of HRP (see Scheme 4). The catalytic action of HRP leads to an increase of the reduction peak in the cyclic voltammogram and the concomitant decrease of the anodic peak. The enzymatic recycling by HRP results in an eight times larger signal for the same MIP system upon addition of peroxide. The authors claim that this signal amplification leads to a shift of the lower limit of detection by two orders of magnitude from $3.9 \mu \mathrm{M}$ to $28 \mathrm{nM}$. The second system used the same polypyrrole-based MIP for kanamycin, but used 1,1'-ferrocenedicarboxylic acid as the redox marker and glucose oxidase (GOx). In the presence of glucose-the co-substrate of GOx-the LOD was shifted down to $23 \mathrm{nM}$, a value comparable with the HRP system. This highly effective principle may be extended for other analytes and the application of alternative electro-enzymatic recycling systems.

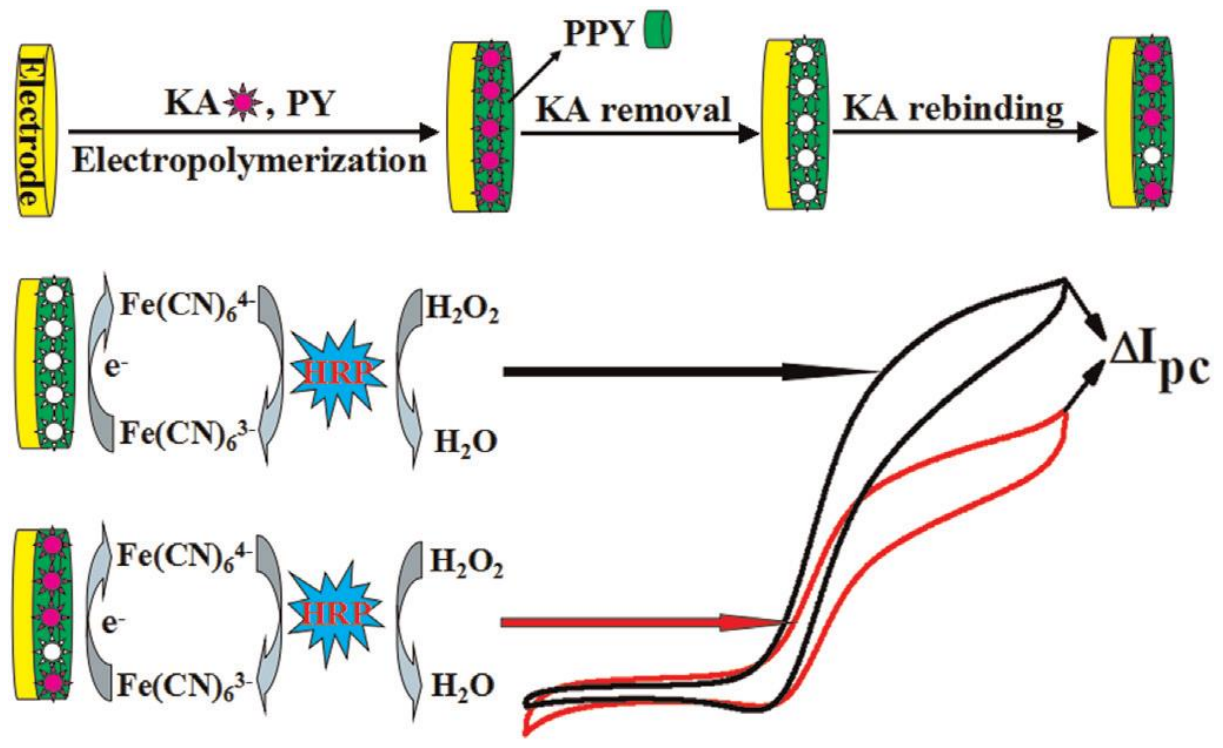

Scheme 4. Preparation scheme of a polypyrrole-based (PPY) MIP for kanamycin (KA) with electrochemical readout using signal amplification by electro-enzymatic recycling of the redox marker ferricyanide. Reproduced from Ref. [82], with permission. Copyright from Elsevier (2017). 


\subsection{Enzyme-Labels in MIP-Based Affinity Sensors}

In 1993, Mosbach and co-workers presented the development of the first molecularly imprinted sorbent assay for the detection of diazepam and theophylline [83]. This method is analogous to competitive immunoassays with the antibody replaced by a MIP. The latter is incubated in a mixture containing both the analyte and a labeled analyte, and the analyte concentration can be assessed from the tracer signal, which decreases with increasing analyte concentration. Since then, several publications have addressed the design and improvement of this technique employing, e.g., different labels and thus readout methods [84]. Besides radiochemical or fluorescent tracers, enzymes have been conjugated with the target molecule, thus facilitating the analyte quantification via an enzymatic reaction (see Scheme 3).

The first enzyme-labeled molecularly imprinted sorbent assay was reported by Surugiu et al. in 2000 [85]. The antigen 2,4-dichlorophenoxyacetic acid was coupled to tobacco peroxidase enabling colorimetric $\left(o-\mathrm{PD} / \mathrm{H}_{2} \mathrm{O}_{2}\right)$ as well as chemiluminescent (luminol $/ \mathrm{H}_{2} \mathrm{O}_{2}$ ) detection with linear measuring ranges of $40-600 \mu \mathrm{g} \cdot \mathrm{mL}^{-1}$ and $1-200 \mu \mathrm{g} \cdot \mathrm{mL}^{-1}$, respectively. This setup was further developed by coating microtiter plates with imprinted polymer microspheres enabling analyses in a high-throughput format [86], as well as by coating glass capillaries enabling flow-injection competitive assays yielding a dynamic range of $5 \mathrm{pg} / \mathrm{mL}$ to $100 \mathrm{ng} / \mathrm{mL}$ in a discontinuous detection mode [87].

Piletsky et al. developed imprinted microplates for the detection of epinephrine and atrazine [88]. Here, the monomers were directly polymerized on the microplate walls in the presence of the template. The analytes were conjugated with HRP and the reaction with 2,2'-azino-bis(3-ethylbenzothiazoline-6-sulphonic acid (ABTS) and $\mathrm{H}_{2} \mathrm{O}_{2}$ was detected. A comparable approach was used by Wang et al. for the detection of estrone in environmental water [89] and by Chianella et al. for the detection of vancomycin in buffer and blood plasma [90]. The latter developed an assay with a high sensitivity and a detection limit of $2.5 \mathrm{pM}$, which even outperformed analogous immunoassays. Similarly high sensitivity was obtained for an isoproturon-MIP developed by Li et al. by applying electrochemical luminescence [91]. GOx was used as the tracer enzyme and the luminescence signal was detected after the addition of glucose and luminol, yielding a linear measuring range from $90 \mathrm{pM}$ up to $5 \mathrm{nM}$ and a detection limit of $4 \mathrm{pM}$.

An electrochemical readout has been used for the detection of oxytetracycline [92]. The analyte was labeled with HRP and the activity towards the oxidation of hydroquinone in the presence of $\mathrm{H}_{2} \mathrm{O}_{2}$ was detected by differential pulse voltammetry, yielding a detection limit of the sensor of $0.65 \mathrm{nM}$ (see Scheme 5).

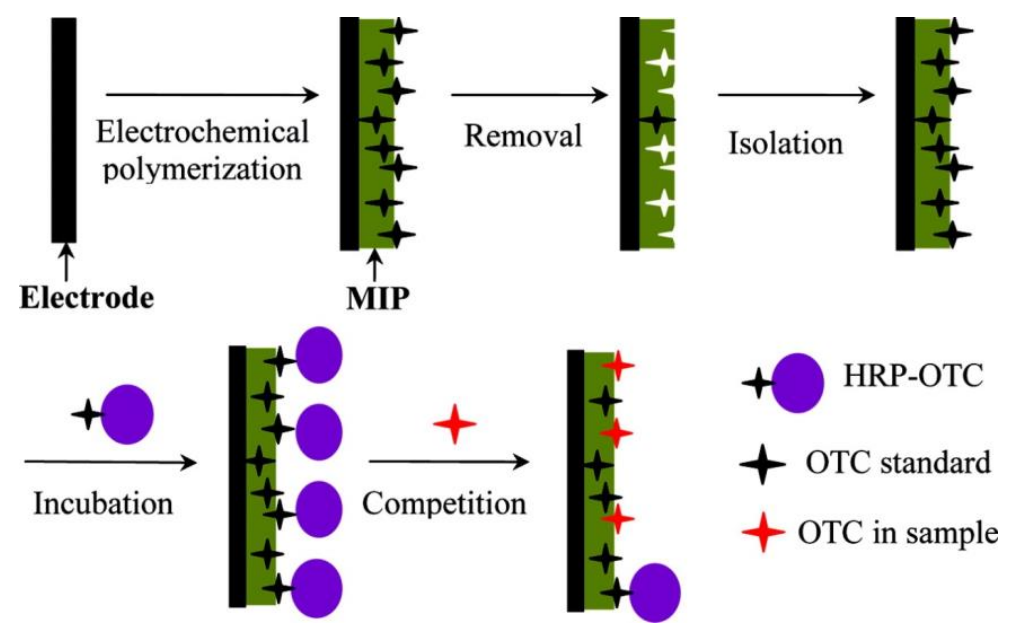

Scheme 5. Schematic representation of MIP sensor preparation for oxytetracycline (OTC) and the detection principle based on amplification by the horseradish peroxidase-labeled analyte (HRP-OTC). Reproduced from Ref. [92], with permission. Copyright from American Chemical Society (2017). 


\subsection{Combinations of MIPs with the Enzymatic Conversion of the Analyte}

Pretreatment of the analyte by an enzyme can lead to a broadened analyte spectrum by the conversion of "non-target" substances into target analogs or to benefits regarding the measuring conditions (see Scheme 3). Additionally, integrated MIP/enzyme architectures can allow for the elimination of interferences.

A family of electrochemical MIP sensors for the non-steroidal antiestrogen tamoxifen (TAM) and the analgesic drugs paracetamol and aminopyrine was prepared by electropolymerization. For these three electroactive targets, the signal was generated by a redox marker and by the direct anodic oxidation of the target at the MIP-covered electrode. For improving the selectivity and to prevent fouling of the electrode surface, the target analyte was enzymatically converted before the interaction with the MIP-covered electrode.

Signal generation of the TAM sensor by the anodic oxidation of the target leads to a continuous signal decrease in a series of measurements. Obviously, an insulating film is formed from the oxidation products. In order to prevent this adverse effect, another electrode reaction was applied [93]. Pretreatment of the TAM solution with hydrogen peroxide in presence of HRP generated an oxidation product which can be reduced at $0 \mathrm{~V}$. At this potential, fouling of the electrode by formation of a polymer film is circumvented. In the present stage of development, the enzymatic reaction has to be performed in solution because the harsh regeneration of the MIP is not compatible with the stability of the enzyme.

Different electrochemical sensors for paracetamol have been described in the literature [94-99] which indicate either the change of diffusional permeability of the MIP layer for a redox marker or the anodic oxidation of paracetamol (PAR). Both methods have severe problems: As described for TAM, the anodic oxidation of phenolic substances leads to an insulating cover and the decrease of the ferricyanide signal is prone to several interferences. To overcome these problems, PAR was enzymatically converted before interaction with the electrochemical MIP-sensor. Combinations of the MIP-electrode with different enzymatic reactions are presented in Scheme 6: The target paracetamol was pretreated with tyrosinase in order to indicate the product at low electrode potential, where electrochemical interferences by ascorbic acid are suppressed and the fouling of the electrode prevented.

The copper enzyme tyrosinase converts a broad spectrum of phenolic compounds using ambient oxygen as the electron acceptor [100-104]. Among them, PAR is converted in two consecutive one-electron oxidation steps into $\mathrm{N}$-acetyl-p-benzoquinone (4-AOBQ) [105] (see Scheme 6). This product generates a cathodic current signal at potentials below $-0.1 \mathrm{~V}$ [106]. Tyrosinase-catalyzed oxidation of paracetamol has been applied in both an amperometric biosensor for monitoring the degradation of paracetamol and the elimination of its interference in a glucose oxidase-based glucose electrode [107].

The treatment of PAR with tyrosinase resulted in the abolishment of the anodic current signal at $0.6 \mathrm{~V}$ and the formation of the cathodic signal at $-0.1 \mathrm{~V}$ [108]. The current of the PAR-MIP electrode at $-0.1 \mathrm{~V}$ increased linearly between $2.5 \mu \mathrm{M}$ and $335 \mu \mathrm{M}\left(\mathrm{R}^{2}=0.9969\right)$ and approached saturation above $550 \mu \mathrm{M}$. Most important, the interfering signals for ascorbic acid and uric acid are completely absent, but also the signals for L-DOPA and catechol are reduced to only 20 percent of the signal for paracetamol.

Furthermore the extension of the analyte spectrum by enzymatic pretreatment of the sample has been demonstrated: Phenacetin - a drug which has been withdrawn from the market—is converted by a non-specific esterase to phenetidine [108] (see Scheme 6). Whilst phenacetin did not generate an oxidation current at $0.6 \mathrm{~V}$, its treatment with esterase brought about concentration dependent signals. Control experiments with phenetidine showed in the DPVs a peak at the same potential [109]. The MIP did not discriminate the very similar substances paracetamol and $p$-phenetidine and showed comparable sensitivities for both substances. This result shows that the combination of the esterase catalyzed hydrolysis with the MIP-covered electrode allows the measurement of phenacetin. 


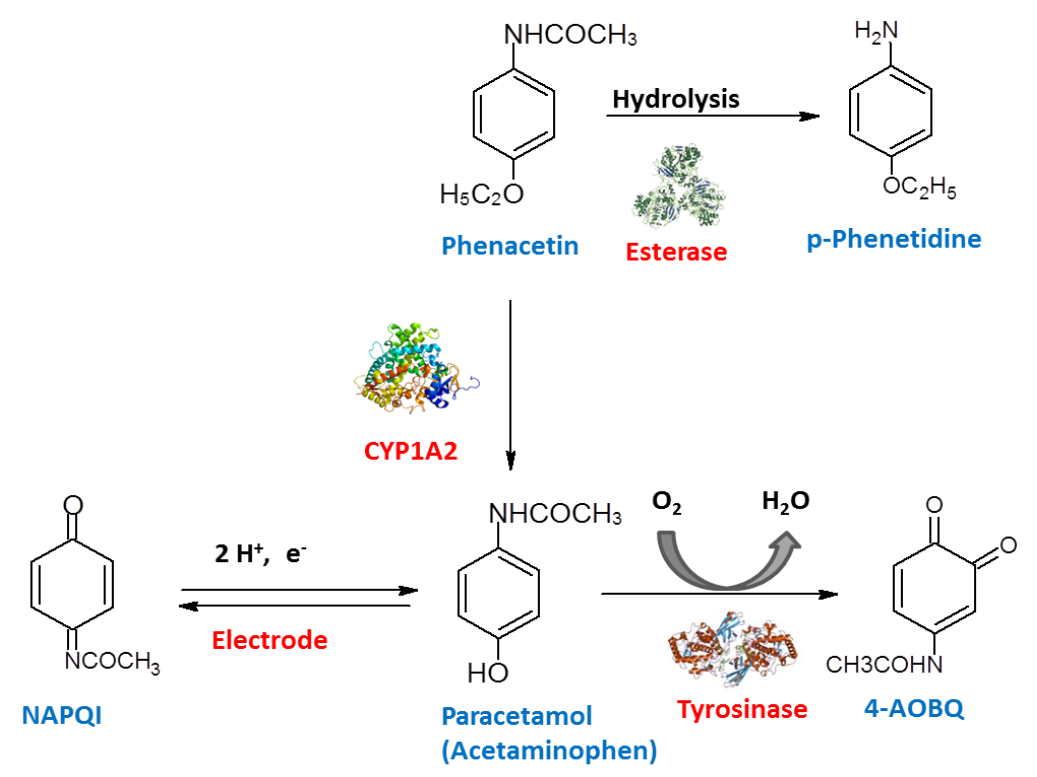

Scheme 6. Enzymatic and electrochemical conversions of paracetamol. Reproduced from Ref. [108], with permission. Copyright from John Wiley and Sons (2016).

As an alternative to the esterolytic conversion of phenacetin into an electroactive product, it was checked whether horseradish peroxidase catalyzes the O-dealkylation to paracetamol. Contrary to the effective catalysis of N-dealkylation of aminopyrine by HRP [110], the formation of an electroactive product was not observed.

Aminopyrine (AP) is metabolized by liver P450s and HRP to formaldehyde and aminoantipyrine (AAP), which is devoid of the two methyl groups at position N4. A MIP electrode for the target AAP recognized both AAP and AP with comparable sensitivity [110]. Both HRP and the mini-enzyme-Microperoxidase-11 (MP-11) were immobilized on top of the MIP for AAP. This new approach combines substrate conversion and the specificity of target recognition by a MIP sub-layer. In this hierarchical architecture, the peroxide dependent conversion of AP takes place in the layer on top of a product-imprinted electropolymer. In the peroxide dependent oxidation of AP (but not of AAP) catalyzed by both HRP and MP-11, an intermediate was formed which generated a cathodic current at $0 \mathrm{~V}$ at the glassy carbon electrode. Uric acid gave no response since it is not electroactive at $0 \mathrm{~V}$. The contribution of ascorbic acid was also completely suppressed by the action of the MIP layer and oxidation with peroxide. Therefore, the enzyme/MIP-sensor indicates only AP (also in the presence of AAP) and prevents interferences by ascorbic acid or uric acid.

\section{Conclusions}

Up to now the field of MIP-sensors-both for low and high molecular weight analytes-has been dominated by electrochemical transducers which indicate mostly a redox marker or an electroactive analyte. Electrochemical methods have been successfully applied in MIP-sensors for drugs or environmental analysis. On the other hand, QCM and SPR are appropriate means for the indication of macromolecules. The application of enzymes in combination with MIP-sensors has the potential to "upgrade" their analytical performance. Up to now, the degree of applying enzymes in the preparation of MIPs and in signal generation for analyte recognition is at different levels of development.

Enzyme-initiated polymerization is still at the initial stage of development. Whether it will compete with the established methods such as electropolymerization, chemical nanoparticle synthesis, and self-polymerization still remains to be seen. The need of immobilizing the enzyme is an additional working step. 
The application of enzymes in the removal of the template is presently restricted to proteinase $\mathrm{K}$ for removing proteins. For oligomeric proteins, splitting into subunits by chaotropic reagents seems more straightforward. On the other hand, the application of nucleases for nucleic acids, lipases for lipids, and glycosidases for carbohydrates may come in the near future.

Enzyme labels are the key in highly sensitive luminescence-based MIP-binding assays and in electro-enzymatic recycling for signal amplification.

The enzymatic pretreatment of a target analyte can generate a product which is indicated at a lower electrode potential or a "non-target" substance that can be converted into a target analog. Integrated MIP/enzyme architectures allow for the elimination of interferences in the detection of drugs.

Acknowledgments: The authors gratefully acknowledge financial support from Deutsche Forschungsgemeinschaft (DFG) within the framework of the German Excellence Initiative Unicat (EXC 314), ERA-Chemistry (2014, 61133), and Turkish-German University Scientific Research Projects Commission under the Grant No. $2016 \mathrm{BF} 0011$ for financial support. KH and AFC acknowledge the European Union FP7 Marie Curie programme (CHEBANA, PITN-GA-2010-264772) and the Regional Council of Picardy (BIOMIP project) for funding.

Conflicts of Interest: The authors declare no conflict of interest.

\section{References}

1. Wulff, G. Molecular Imprinting in Cross-Linked Materials with the Aid of Molecular Templates-A Way towards Artificial Antibodies. Angew. Chem. Int. Ed. 1995, 34, 1812-1832. [CrossRef]

2. Haupt, K.; Mosbach, K. Molecularly imprinted polymers and their use in biomimetic sensors. Chem. Rev. 2000, 100, 2495-2504. [CrossRef] [PubMed]

3. Chen, L.; Xu, S.; Li, J. Recent advances in molecular imprinting technology: Current status, challenges and highlighted applications. Chem. Soc. Rev. 2011, 40, 2922. [CrossRef] [PubMed]

4. Hayden, O.; Lieberzeit, P.A.; Blaas, D.; Dickert, F.L. Artificial antibodies for bioanalyte detection - Sensing viruses and proteins. Adv. Funct. Mater. 2006, 16, 1269-1278. [CrossRef]

5. Alexander, C.; Andersson, H.S.; Andersson, L.I.; Ansell, R.J.; Kirsch, N.; Nicholls, I.A.; O'Mahony, J.; Whitcombe, M.J. Molecular imprinting science and technology: A survey of the literature for the years up to and including 2003. J. Mol. Recognit. 2006, 19, 106-180. [CrossRef] [PubMed]

6. Whitcombe, M.J.; Kirsch, N.; Nicholls, I.A. Molecular imprinting science and technology: A survey of the literature for the years 2004-2011. J. Mol. Recognit. 2014, 27, 297-401. [PubMed]

7. Erdőssy, J.; Horváth, V.; Yarman, A.; Scheller, F.W.; Gyurcsányi, R.E. Electrosynthesized molecularly imprinted polymers for protein recognition. TrAC Trends Anal. Chem. 2016, 79, 179-190. [CrossRef]

8. Menger, M.; Yarman, A.; Erdőssy, J.; Yildiz, H.; Gyurcsányi, R.; Scheller, F. MIPs and Aptamers for Recognition of Proteins in Biomimetic Sensing. Biosensors 2016, 6, 35. [CrossRef] [PubMed]

9. Uzun, L.; Turner, A.P.F. Molecularly-imprinted polymer sensors: Realising their potential. Biosens. Bioelectron. 2016, 76, 131-144. [CrossRef] [PubMed]

10. Daoud Attieh, M.; Zhao, Y.; Elkak, A.; Falcimaigne-Cordin, A.; Haupt, K. Enzyme-initiated Free-Radical Polymerization of Molecularly Imprinted Polymer Nanogels on a Solid Phase with Immobilized Radical Source. Angew. Chem. Int. Ed. 2017, 56, 3339-3343. [CrossRef] [PubMed]

11. Ambrosini, S.; Beyazit, S.; Haupt, K.; Tse Sum Bui, B. Solid-phase synthesis of molecularly imprinted nanoparticles for protein recognition. Chem. Commun. 2013, 49, 6746. [CrossRef] [PubMed]

12. Xu, J.; Ambrosini, S.; Tamahkar, E.; Rossi, C.; Haupt, K.; Tse Sum Bui, B. Toward a universal method for preparing molecularly imprinted polymer nanoparticles with antibody-like affinity for proteins. Biomacromolecules 2016, 17, 345-353. [CrossRef] [PubMed]

13. Cutivet, A.; Schembri, C.; Kovensky, J.; Haupt, K. Molecularly imprinted microgels as enzyme inhibitors. J. Am. Chem. Soc. 2009, 131, 14699-14702. [CrossRef] [PubMed]

14. Matsunaga, T.; Hishiya, T.; Takeuchi, T. Surface plasmon resonance sensor for lysozyme based on molecularly imprinted thin films. Anal. Chim. Acta 2007, 591, 63-67. [CrossRef] [PubMed]

15. Liu, L.; Zheng, J.; Fang, G.; Xie, W. Improvement of the homogeneity of protein-imprinted polymer films by orientated immobilization of the template. Anal. Chim. Acta 2012, 726, 85-92. [CrossRef] [PubMed] 
16. Zheng, C.; Zhang, X.-L.; Liu, W.; Liu, B.; Yang, H.-H.; Lin, Z.-A.; Chen, G.-N. A Selective Artificial Enzyme Inhibitor Based on Nanoparticle-Enzyme Interactions and Molecular Imprinting. Adv. Mater. 2013, 25, 5922-5927. [CrossRef] [PubMed]

17. Guerreiro, A.; Poma, A.; Karim, K.; Moczko, E.; Takarada, J.; de Vargas-Sansalvador, I.P.; Turner, N.; Piletska, E.; de Magalhães, C.S.; Glazova, N.; et al. Influence of Surface-Imprinted Nanoparticles on Trypsin Activity. Adv. Healthc. Mater. 2014, 3, 1426-1429. [CrossRef] [PubMed]

18. Jetzschmann, K.J.; Jágerszki, G.; Dechtrirat, D.; Yarman, A.; Gajovic-Eichelmann, N.; Gilsing, H.-D.; Schulz, B.; Gyurcsányi, R.E.; Scheller, F.W. Vectorially Imprinted Hybrid Nanofilm for Acetylcholinesterase Recognition. Adv. Funct. Mater. 2015, 25, 5178-5183. [CrossRef]

19. Kamon, Y.; Matsuura, R.; Kitayama, Y.; Ooya, T.; Takeuchi, T. Precisely controlled molecular imprinting of glutathione-s-transferase by orientated template immobilization using specific interaction with an anchored ligand on a gold substrate. Polym. Chem. 2014, 5, 4764. [CrossRef]

20. Wang, S.; Ye, J.; Bie, Z.; Liu, Z. Affinity-tunable specific recognition of glycoproteins via boronate affinity-based controllable oriented surface imprinting. Chem. Sci. 2014, 5, 1135-1140. [CrossRef]

21. Peng, L.; Yarman, A.; Jetzschmann, K.J.; Jeoung, J.-H.; Schad, D.; Dobbek, H.; Wollenberger, U.; Scheller, F.W. Molecularly imprinted electropolymer for a hexameric heme protein with direct electron transfer and peroxide electrocatalysis. Sensors 2016, 16, 272. [CrossRef] [PubMed]

22. Lettau, K.; Warsinke, A.; Katterle, M.; Danielsson, B.; Scheller, F.W. A Bifunctional Molecularly Imprinted Polymer (MIP): Analysis of Binding and Catalysis by a Thermistor. Angew. Chem. Int. Ed. 2006, 45, 6986-6990. [CrossRef] [PubMed]

23. Wulff, G.; Liu, J. Design of biomimetic catalysts by molecular imprinting in synthetic polymers: The role of transition state stabilization. Acc. Chem. Res. 2012, 45, 239-247. [CrossRef] [PubMed]

24. Wulff, G.; Vesper, W.; Grobe-Einsler, R.; Sarhan, A. Enzyme-analogue built polymers, 4. On the synthesis of polymers containing chiral cavities and their use for the resolution of racemates. Die Makromol. Chem. 1977, 178, 2799-2816. [CrossRef]

25. De Jesus Rodrigues Santos, W.; Lima, P.R.; Tarley, C.R.T.; Kubota, L.T. A catalytically active molecularly imprinted polymer that mimics peroxidase based on hemin: Application to the determination of p-aminophenol. Anal. Bioanal. Chem. 2007, 389, 1919-1929. [CrossRef] [PubMed]

26. Lakshmi, D.; Bossi, A.; Whitcombe, M.J.; Chianella, I.; Fowler, S.A.; Subrahmanyam, S.; Piletska, E.V.; Piletsky, S.A. Electrochemical Sensor for Catechol and Dopamine Based on a Catalytic Molecularly Imprinted Polymer-Conducting Polymer Hybrid Recognition Element. Anal. Chem. 2009, 81, 3576-3584. [CrossRef] [PubMed]

27. Huang, X.; Yin, Y.; Liu, Y.; Bai, X.; Zhang, Z.; Xu, J.; Shen, J.; Liu, J. Incorporation of glutathione peroxidase active site into polymer based on imprinting strategy. Biosens. Bioelectron. 2009, 25, 657-660. [CrossRef] [PubMed]

28. Sode, K.; Ohta, S.; Yanai, Y.; Yamazaki, T. Construction of a molecular imprinting catalyst using target analogue template and its application for an amperometric fructosylamine sensor. Biosens. Bioelectron. 2003, 18, 1485-1490. [CrossRef]

29. Lohmann, W.; Karst, U. Biomimetic modeling of oxidative drug metabolism. Anal. Bioanal. Chem. 2008, 391, 79-96. [CrossRef] [PubMed]

30. Resmini, M. Molecularly imprinted polymers as biomimetic catalysts. Anal. Bioanal. Chem. 2012, 402, 3021-3026. [CrossRef] [PubMed]

31. Dechtrirat, D.; Jetzschmann, K.J.; Stöcklein, W.F.M.; Scheller, F.W.; Gajovic-Eichelmann, N. Protein rebinding to a surface-confined imprint. Adv. Funct. Mater. 2012, 22, 5231-5237. [CrossRef]

32. Poma, A.; Turner, A.P.F.; Piletsky, S.A. Advances in the manufacture of MIP nanoparticles. Trends Biotechnol. 2010, 28, 629-637. [CrossRef] [PubMed]

33. Pérez, N.; Whitcombe, M.J.; Vulfson, E.N. Surface imprinting of cholesterol on submicrometer core-shell emulsion particles. Macromolecules 2001, 34, 830-836. [CrossRef]

34. Li, L.; He, X.; Chen, L.; Zhang, Y. Preparation of novel bovine hemoglobin surface-imprinted polystyrene nanoparticles with magnetic susceptibility. Sci. China Ser. B Chem. 2009, 52, 1402-1411. [CrossRef]

35. Poma, A.; Guerreiro, A.; Whitcombe, M.J.; Piletska, E.V.; Turner, A.P.F.; Piletsky, S.A. Solid-Phase Synthesis of Molecularly Imprinted Polymer Nanoparticles with a Reusable Template- "Plastic Antibodies". Adv. Funct. Mater. 2013, 23, 2821-2827. [CrossRef] [PubMed] 
36. Li, Y.; Li, Y.; Hong, M.; Bin, Q.; Lin, Z.; Lin, Z.; Cai, Z.; Chen, G. Highly sensitive protein molecularly imprinted electro-chemical sensor based on gold microdendrites electrode and prussian blue mediated amplification. Biosens. Bioelectron. 2013, 42, 612-617. [CrossRef] [PubMed]

37. Liu, Y.; Shi, X.-W.; Kim, E.; Robinson, L.M.; Nye, C.K.; Ghodssi, R.; Rubloff, G.W.; Bentley, W.E.; Payne, G.F. Chitosan to electroaddress biological components in lab-on-a-chip devices. Carbohydr. Polym. 2011, 84, 704-708. [CrossRef]

38. Malitesta, C.; Losito, I.; Zambonin, P.G. Molecularly imprinted electrosynthesized polymers: New materials for biomimetic sensors. Anal. Chem. 1999, 71, 1366-1370. [CrossRef] [PubMed]

39. Panasyuk, T.L.; Mirsky, V.M.; Piletsky, S.A.; Wolfbeis, O.S. Electropolymerized molecularly imprinted polymers as receptor layers in capacitive chemical sensors. Anal. Chem. 1999, 71, 4609-4613. [CrossRef]

40. Ramanavicius, A.; Oztekin, Y.; Ramanaviciene, A. Electrochemical formation of polypyrrole-based layer for immunosensor design. Sens. Actuators B Chem. 2014, 197, 237-243. [CrossRef]

41. Menaker, A.; Syritski, V.; Reut, J.; Öpik, A.; Horváth, V.; Gyurcsányi, R.E. Electrosynthesized Surface-Imprinted Conducting Polymer Microrods for Selective Protein Recognition. Adv. Mater. 2009, 21, 2271-2275. [CrossRef]

42. Chen, H.-J.; Zhang, Z.-H.; Xie, D.; Cai, R.; Chen, X.; Liu, Y.-N.; Yao, S.-Z. Surface-Imprinting Sensor Based on Carbon Nanotubes/Graphene Composite for Determination of Bovine Serum Albumin. Electroanalysis 2012, 24, 2109-2116. [CrossRef]

43. Karimian, N.; Vagin, M.; Zavar, M.H.A.; Chamsaz, M.; Turner, A.P.F.; Tiwari, A. An ultrasensitive molecularly-imprinted human cardiac troponin sensor. Biosens. Bioelectron. 2013, 50, 492-498. [CrossRef] [PubMed]

44. Wang, X.; Dong, J.; Ming, H.; Ai, S. Sensing of glycoprotein via a biomimetic sensor based on molecularly imprinted polymers and graphene-Au nanoparticles. Analyst 2013, 138, 1219. [CrossRef] [PubMed]

45. Moreira, F.T.C.; Sharma, S.; Dutra, R.A.F.; Noronha, J.P.C.; Cass, A.E.G.; Sales, M.G.F. Protein-responsive polymers for point-of-care detection of cardiac biomarker. Sens. Actuators B Chem. 2014, 196, 123-132. [CrossRef]

46. Bognár, J.; Szucs, J.; Dorkõ, Z.; Horváth, V.; Gyurcsányi, R.E. Nanosphere lithography as a versatile method to generate surface-imprinted polymer films for selective protein recognition. Adv. Funct. Mater. 2013, 23, 4703-4709. [CrossRef]

47. Ceolin, G.; Orbán, Á.; Kocsis, V.; Gyurcsányi, R.E.; Kézsmárki, I.; Horváth, V. Electrochemical template synthesis of protein-imprinted magnetic polymer microrods. J. Mater. Sci. 2013, 48, 5209-5218. [CrossRef]

48. Lee, H.; Dellatore, S.M.; Miller, W.M.; Messersmith, P.B. Mussel-inspired surface chemistry for multifunctional coatings. Science 2007, 318, 426-430. [CrossRef] [PubMed]

49. Waite, J.H.; Qin, X. Polyphosphoprotein from the adhesive pads of Mytilus edulis. Biochemistry 2001, 40, 2887-2893. [CrossRef] [PubMed]

50. Zhou, W.-H.; Lu, C.-H.; Guo, X.-C.; Chen, F.-R.; Yang, H.-H.; Wang, X.-R. Mussel-inspired molecularly imprinted polymer coating superparamagnetic nanoparticles for protein recognition. J. Mater. Chem. 2010, 20, 880. [CrossRef]

51. Zhang, M.; Zhang, X.; He, X.; Chen, L.; Zhang, Y. A self-assembled polydopamine film on the surface of magnetic nanoparticles for specific capture of protein. Nanoscale 2012, 4, 3141. [CrossRef] [PubMed]

52. Yao, G.-H.; Liang, R.-P.; Huang, C.-F.; Wang, Y.; Qiu, J.-D. Surface plasmon resonance sensor based on magnetic molecularly imprinted polymers amplification for pesticide recognition. Anal. Chem. 2013, 85, 11944-11951. [CrossRef] [PubMed]

53. Lv, Y.; Qin, Y.; Svec, F.; Tan, T. Molecularly imprinted plasmonic nanosensor for selective SERS detection of protein biomarkers. Biosens. Bioelectron. 2016, 80, 433-441. [CrossRef] [PubMed]

54. Nematollahzadeh, A.; Shojaei, A.; Abdekhodaie, M.J.; Sellergren, B. Molecularly imprinted polydopamine nano-layer on the pore surface of porous particles for protein capture in HPLC column. J. Colloid Interface Sci. 2013, 404, 117-126. [CrossRef] [PubMed]

55. Xia, Z.; Lin, Z.; Xiao, Y.; Wang, L.; Zheng, J.; Yang, H.; Chen, G. Facile synthesis of polydopamine-coated molecularly imprinted silica nanoparticles for protein recognition and separation. Biosens. Bioelectron. 2013, 47, 120-126. [CrossRef] [PubMed]

56. Chen, T.; Shao, M.; Xu, H.; Zhuo, S.; Liu, S.; Lee, S.-T. Molecularly imprinted polymer-coated silicon nanowires for protein specific recognition and fast separation. J. Mater. Chem. 2012, 22, 3990-3996. [CrossRef] 
57. Lin, Z.; Wang, J.; Tan, X.; Sun, L.; Yu, R.; Yang, H.; Chen, G. Preparation of boronate-functionalized molecularly imprinted monolithic column with polydopamine coating for glycoprotein recognition and enrichment. J. Chromatogr. A 2013, 1319, 141-147. [CrossRef] [PubMed]

58. Tretjakov, A.; Syritski, V.; Reut, J.; Boroznjak, R.; Volobujeva, O.; Öpik, A. Surface molecularly imprinted polydopamine films for recognition of immunoglobulin G. Microchim. Acta 2013, 180, 1433-1442. [CrossRef]

59. Li, L.; Fan, L.; Dai, Y.; Kan, X. Recognition and determination of bovine hemoglobin using a gold electrode modified with gold nanoparticles and molecularly imprinted self-polymerized dopamine. Microchim. Acta 2015, 182, 2477-2483. [CrossRef]

60. Liu, R.; Sha, M.; Jiang, S.; Luo, J.; Liu, X. A facile approach for imprinting protein on the surface of multi-walled carbon nanotubes. Talanta 2014, 120, 76-83. [CrossRef] [PubMed]

61. Yu, B.; Liu, J.; Liu, S.; Zhou, F. Pdop layer exhibiting zwitterionicity: A simple electrochemical interface for governing ion permeability. Chem. Commun. 2010, 46, 5900. [CrossRef] [PubMed]

62. Hollmann, F.; Arends, I.W.C.E. Enzyme initiated radical polymerizations. Polymers 2012, 4, 759-793. [CrossRef]

63. Kobayashi, S.; Makino, A. Enzymatic polymer synthesis: An opportunity for green polymer chemistry. Chem. Rev. 2009, 109, 5288-5353. [CrossRef] [PubMed]

64. Lopes, G.R.; Pinto, D.C.G.A.; Silva, A.M.S. Horseradish peroxidase (HRP) as a tool in green chemistry. RSC Adv. 2014, 4, 37244. [CrossRef]

65. Lizardi, P.M.; Engelberg, A. Rapid isolation of RNA using proteinase K and sodium perchlorate. Anal. Biochem. 1979, 98, 116-122. [CrossRef]

66. Rao, M.B.; Tanksale, A.M.; Ghatge, M.S.; Deshpande, V. Molecular and biotechnological aspects of microbial proteases. Microbiol. Mol. Biol. Rev. 1998, 62, 597-635. [PubMed]

67. Hawkins, D.M.; Stevenson, D.; Reddy, S.M. Investigation of protein imprinting in hydrogel-based molecularly imprinted polymers (HydroMIPs). Anal. Chim. Acta 2005, 542, 61-65. [CrossRef]

68. Moreira, F.T.C.; Ferreira, M.J.M.S.; Puga, J.R.T.; Sales, M.G.F. Screen-printed electrode produced by printed-circuit board technology. Application to cancer biomarker detection by means of plastic antibody as sensing material. Sens. Actuators B Chem. 2016, 223, 927-935. [CrossRef]

69. Dechtrirat, D.; Gajovic-Eichelmann, N.; Bier, F.F.; Scheller, F.W. Hybrid Material for Protein Sensing Based on Electrosynthesized MIP on a Mannose Terminated Self-Assembled Monolayer. Adv. Funct. Mater. 2014, 24, 2233-2239. [CrossRef]

70. Bosserdt, M.; Gajovic-Eichelman, N.; Scheller, F.W. Modulation of direct electron transfer of cytochrome c by use of a molecularly imprinted thin film. Anal. Bioanal. Chem. 2013, 405, 6437-6444. [CrossRef] [PubMed]

71. Reddy, S.M.; Sette, G.; Phan, Q. Electrochemical probing of selective haemoglobin binding in hydrogel-based molecularly imprinted polymers. Electrochim. Acta 2011, 56, 9203-9208. [CrossRef]

72. Liu, Y.T.; Deng, J.; Xiao, X.L.; Ding, L.; Yuan, Y.L.; Li, H.; Li, X.T.; Yan, X.N.; Wang, L.L. Electrochemical sensor based on a poly(para-aminobenzoic acid) film modified glassy carbon electrode for the determination of melamine in milk. Electrochim. Acta 2011, 56, 4595-4602. [CrossRef]

73. Xue, X.; Wei, Q.; Wu, D.; Li, H.; Zhang, Y.; Feng, R.; Du, B. Determination of methyl parathion by a molecularly imprinted sensor based on nitrogen doped graphene sheets. Electrochim. Acta 2014, 116, 366-371. [CrossRef]

74. Yu, H.C.; Huang, X.Y.; Lei, F.H.; Tan, X.C.; Wei, Y.C.; Li, H. Molecularly imprinted electrochemical sensor based on nickel nanoparticle-modified electrodes for phenobarbital determination. Electrochim. Acta 2014, 141, 45-50. [CrossRef]

75. Rezaei, B.; Khalili Boroujeni, M.; Ensafi, A.A. Caffeine electrochemical sensor using imprinted film as recognition element based on polypyrrole, sol-gel, and gold nanoparticles hybrid nanocomposite modified pencil graphite electrode. Biosens. Bioelectron. 2014, 60, 77-83. [CrossRef] [PubMed]

76. Rezaei, B.; Rahmanian, O.; Ensafi, A.A. An electrochemical sensor based on multiwall carbon nanotubes and molecular imprinting strategy for warfarin recognition and determination. Sens. Actuators B Chem. 2014, 196, 539-545. [CrossRef]

77. Pasha, S.K.; Kaushik, A.; Vasudev, A.; Snipes, S.A.; Bhansali, S. Electrochemical Immunosensing of Saliva Cortisol. J. Electrochem. Soc. 2013, 161, B3077-B3082. [CrossRef]

78. Florea, A.; Guo, Z.; Cristea, C.; Bessueille, F.; Vocanson, F.; Goutaland, F.; Dzyadevych, S.; Săndulescu, R.; Jaffrezic-Renault, N. Anticancer drug detection using a highly sensitive molecularly 
imprinted electrochemical sensor based on an electropolymerized microporous metal organic framework. Talanta 2015, 138, 71-76. [CrossRef] [PubMed]

79. Prasad, B.B.; Prasad, A.; Tiwari, M.P. Multiwalled carbon nanotubes-ceramic electrode modified with substrate-selective imprinted polymer for ultra-trace detection of bovine serum albumin. Biosens. Bioelectron. 2013, 39, 236-243. [CrossRef] [PubMed]

80. Cieplak, M.; Szwabinska, K.; Sosnowska, M.; Chandra, B.K.C.; Borowicz, P.; Noworyta, K.; D’Souza, F.; Kutner, W. Selective electrochemical sensing of human serum albumin by semi-covalent molecular imprinting. Biosens. Bioelectron. 2015, 74, 960-966. [CrossRef] [PubMed]

81. Cai, D.; Ren, L.; Zhao, H.; Xu, C.; Zhang, L.; Yu, Y.; Wang, H.; Lan, Y.; Roberts, M.F.; Chuang, J.H.; et al. A molecular-imprint nanosensor for ultrasensitive detection of proteins. Nat. Nanotechnol. 2010, 5, 597-601. [CrossRef] [PubMed]

82. Lian, W.; Liu, S.; Wang, L.; Liu, H. A novel strategy to improve the sensitivity of antibiotics determination based on bioelectrocatalysis at molecularly imprinted polymer film electrodes. Biosens. Bioelectron. 2015, 73, 214-220. [CrossRef] [PubMed]

83. Vlatakis, G.; Andersson, L.I.; Müller, R.; Mosbach, K. Drug assay using antibody mimics made by molecular imprinting. Nature 1993, 361, 645-647. [CrossRef] [PubMed]

84. Baggiani, C.; Anfossi, L.; Giovannoli, C. MIP-based immunoassays: State of the Art, limitations and Perspectives. Mol. Impr. 2013, 1, 41-54. [CrossRef]

85. Surugiu, I.; Ye, L.; Yilmaz, E.; Dzgoev, A.; Danielsson, B.; Mosbach, K.; Haupt, K. An enzyme-linked molecularly imprinted sorbent assay. Analyst 2000, 125, 13-16. [CrossRef]

86. Surugiu, I.; Danielsson, B.; Ye, L.; Mosbach, K.; Haupt, K. Chemiluminescence imaging ELISA using an imprinted polymer as the recognition element instead of an antibody. Anal. Chem. 2001, 73, 487-491. [CrossRef] [PubMed]

87. Surugiu, I.; Svitel, J.; Ye, L.; Haupt, K.; Danielsson, B. Development of a flow injection capillary chemiluminescent ELISA using an imprinted polymer instead of the antibody. Anal. Chem. 2001, 73, 4388-4392. [CrossRef] [PubMed]

88. Piletsky, S.A.; Piletska, E.V.; Bossi, A.; Karim, K.; Lowe, P.; Turner, A.P. Substitution of antibodies and receptors with molecularly imprinted polymers in enzyme-linked and fluorescent assays. Biosens. Bioelectron. 2001, 16, 701-707. [CrossRef]

89. Wang, S.; Xu, Z.; Fang, G.; Zhang, Y.; Liu, B.; Zhu, H. Development of a Biomimetic Enzyme-Linked Immunosorbent Assay Method for the Determination of Estrone in Environmental Water using Novel Molecularly Imprinted Films of Controlled Thickness as Artificial Antibodies. J. Agric. Food Chem. 2009, 57, 4528-4534. [CrossRef] [PubMed]

90. Chianella, I.; Guerreiro, A.; Moczko, E.; Caygill, J.S.; Piletska, E.V.; De Vargas Sansalvador, I.M.P.; Whitcombe, M.J.; Piletsky, S.A. Direct Replacement of Antibodies with Molecularly Imprinted Polymer Nanoparticles in ELISA-Development of a Novel Assay for Vancomycin. Anal. Chem. 2013, 85, 8462-8468. [CrossRef] [PubMed]

91. Li, S.; Tao, H.; Li, J. Molecularly Imprinted Electrochemical Luminescence Sensor Based on Enzymatic Amplification for Ultratrace Isoproturon Determination. Electroanalysis 2012, 24, 1664-1670. [CrossRef]

92. Li, J.; Jiang, F.; Wei, X. Molecularly Imprinted Sensor Based on an Enzyme Amplifier for Ultratrace Oxytetracycline Determination. Anal. Chem. 2010, 82, 6074-6078. [CrossRef]

93. Yarman, A.; Scheller, F. The First Electrochemical MIP Sensor for Tamoxifen. Sensors 2014, 14, 7647-7654. [CrossRef] [PubMed]

94. Gómez-Caballero, A.; Goicolea, M.A.; Barrio, R.J. Paracetamol voltammetric microsensors based on electrocopolymerized-molecularly imprinted film modified carbon fiber microelectrodes. Analyst 2005, 130, 1012. [CrossRef] [PubMed]

95. Özcan, L.; Şahin, Y. Determination of paracetamol based on electropolymerized-molecularly imprinted polypyrrole modified pencil graphite electrode. Sens. Actuators B Chem. 2007, 127, 362-369. [CrossRef]

96. Wang, X.; Luo, J.; Yi, C.; Liu, X. Paracetamol Sensor Based on Molecular Imprinting by Photosensitive Polymers. Electroanalysis 2013, 25, 1907-1916. [CrossRef]

97. Luo, J.; Fan, C.; Wang, X.; Liu, R.; Liu, X. A novel electrochemical sensor for paracetamol based on molecularly imprinted polymeric micelles. Sens. Actuators B Chem. 2013, 188, 909-916. [CrossRef] 
98. Tan, Y.; Zhou, Z.; Wang, P.; Nie, L.; Yao, S. A study of a bio-mimetic recognition material for the BAW sensor by molecular imprinting and its application for the determination of paracetamol in the human serum and urine. Talanta 2001, 55, 337-347. [CrossRef]

99. Pernites, R.; Ponnapati, R.; Felipe, M.J.; Advincula, R. Electropolymerization molecularly imprinted polymer (E-MIP) SPR sensing of drug molecules: Pre-polymerization complexed terthiophene and carbazole electroactive monomers. Biosens. Bioelectron. 2011, 26, 2766-2771. [CrossRef] [PubMed]

100. Carralero Sanz, V.; Mena, M.L.; González-Cortés, A.; Yáñez-Sedeño, P.; Pingarrón, J.M. Development of a tyrosinase biosensor based on gold nanoparticles-modified glassy carbon electrodes: Application to the measurement of a bioelectrochemical polyphenols index in wines. Anal. Chim. Acta 2005, 528, 1-8. [CrossRef]

101. Boujakhrout, A.; Sánchez, A.; Díez, P.; Jiménez-Falcao, S.; Martínez-Ruiz, P.; Peña-Álvarez, M.; Pingarrón, J.M.; Villalonga, R. Decorating graphene oxide/nanogold with dextran-based polymer brushes for the construction of ultrasensitive electrochemical enzyme biosensors. J. Mater. Chem. B 2015, 3, 3518-3524. [CrossRef]

102. Vidal, J.C.; Esteban, S.; Gil, J.; Castillo, J.R. A comparative study of immobilization methods of a tyrosinase enzyme on electrodes and their application to the detection of dichlorvos organophosphorus insecticide. Talanta 2006, 68, 791-799. [CrossRef] [PubMed]

103. Yildiz, H.B.; Castillo, J.; Guschin, D.A.; Toppare, L.; Schuhmann, W. Phenol biosensor based on electrochemically controlled integration of tyrosinase in a redox polymer. Microchim. Acta 2007, 159, 27-34. [CrossRef]

104. Kurbanoglu, S.; Mayorga-Martinez, C.C.; Medina-Sánchez, M.; Rivas, L.; Ozkan, S.A.; Merkoçi, A. Antithyroid drug detection using an enzyme cascade blocking in a nanoparticle-based lab-on-a-chip system. Biosens. Bioelectron. 2015, 67, 670-676. [CrossRef] [PubMed]

105. Valero, E.; Varón, R.; García-Carmona, F. Tyrosinase-Mediated Oxidation of Acetaminophen to 4-Acetamido-o- Benzoquinone. Biol. Chem. 2002, 383, 1931-1939. [CrossRef] [PubMed]

106. Calas-Blanchard, C.; Istamboulié, G.; Bontoux, M.; Plantard, G.; Goetz, V.; Noguer, T. Biosensor-based real-time monitoring of paracetamol photocatalytic degradation. Chemosphere 2015, 131, 124-129. [CrossRef] [PubMed]

107. Wang, J.; Naser, N.; Wollenberger, U. Use of tyrosinase for enzymatic elimination of acetaminophen interference in amperometric sensing. Anal. Chim. Acta 1993, 281, 19-24. [CrossRef]

108. Yarman, A.; Scheller, F.W. MIP-esterase/Tyrosinase Combinations for Paracetamol and Phenacetin. Electroanalysis 2016, 28, 2222-2227. [CrossRef]

109. Bacon, J.; Adams, R.N. Anodic oxidations of aromatic amines. III. Substituted anilines in aqueous media. J. Am. Chem. Soc. 1968, 90, 6596-6599. [CrossRef]

110. Yarman, A.; Scheller, F.W. Coupling biocatalysis with molecular imprinting in a biomimetic sensor. Angew. Chem. Int. Ed. 2013, 52, 11521-11525. [CrossRef] [PubMed]

(C) 2017 by the authors. Licensee MDPI, Basel, Switzerland. This article is an open access article distributed under the terms and conditions of the Creative Commons Attribution (CC BY) license (http://creativecommons.org/licenses/by/4.0/). 